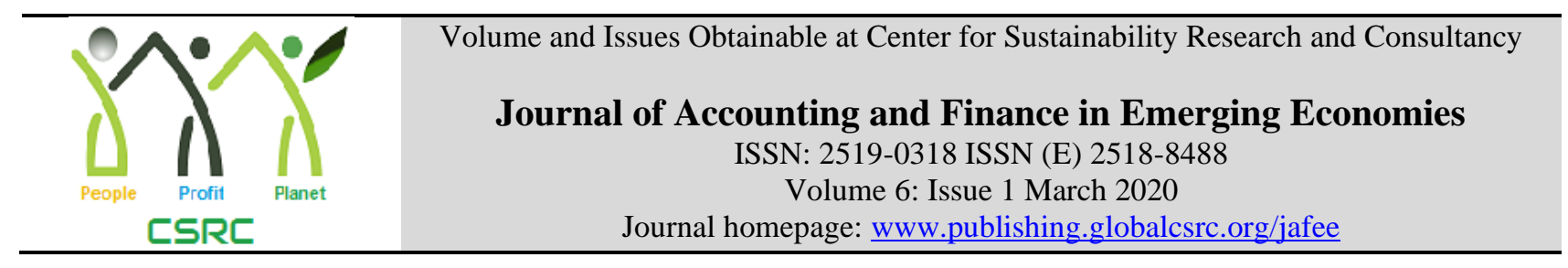

\title{
Impact of Foreign Remittances on Financial Development of Pakistan
}

\author{
${ }^{1}$ Ghulam Mustafa, ${ }^{2}$ Said Zamin Shah, ${ }^{3}$ Asim Iqbal \\ ${ }^{1}$ Department of Economics and Business Administration, Division of Arts and Social Sciences, University of \\ Education, Lahore, Punjab, Pakistan.ghulam.mustafa@ue.edu.pk \\ ${ }^{2}$ Department of Economics, Islamia College University, Peshawar, KPK, Pakistan. \\ syed_economist1983@yahoo.com \\ ${ }^{3}$ Department of Economics and Business Administration, Division of Arts and Social Sciences, University of \\ Education, Lahore, Punjab, Pakistan. asim.iqbal@ue.edu.pk
}

\begin{tabular}{l}
\multicolumn{1}{c}{ ARTICLE DETAILS } \\
\hline History \\
Revised format: February 2020 \\
Available Online: March 2020 \\
\\
\hline Keywords \\
ARDL, Economic Development, \\
Financial Development, Foreign \\
Direct Investment, Remittances
\end{tabular}

JEL Classification:

C13, F22, F43, O16, F37

\begin{abstract}
Purpose: Mostly developing countries are not receiving the remittances with same speed as compared to workers' outflow. This cumbersome situation allows developing countries to go to external source of funding (debt) for economic and financial development-FD. Thus, the purpose of this paper is to investigate the nexus between FD and remittances in Pakistan for the period 1976-2015.

Design/Methodology/Approach: The study utilizes the time series annual data for the period 1976-2015. Data were taken from different sources like world bank data source and different economic surveys of Pakistan. To evaluate the long run relationships between FD and remittances, Auto Regressive Distributed Lag (ARDL) strategy is utilized. Findings: The empirical results indicate that remittances have a significant positive impact on FD (M2/GDP) except for CPS/GDP measure of FD which has insignificant positive coefficient.

Implications/Originality/Value: Most of previous literature measured FD with the ratio of money supply to GDP (M2/GDP) however, the current study measured with two indicators i.e. the ratio of money supply to GDP (M2/GDP) and the ratio of bank credit to GDP (CPS/GDP). This is the main contribution in the literature. The study recommends that remittances channelize financial segment of the country in augmented manner and government should encourage Pakistani expatriates to send the remittance through formal sources (e.g. banks). Financial institutions and intermediaries working in Pakistan should exaggerate the recruitment of remittances with the purpose to make them significant source for loanable funds. In addition to this, the concern department should simplify the procedure for sending remittances.
\end{abstract}

Corresponding author's email address: ghulam.mustafa@ue.edu.pk

Recommended citation: Mustafa, G., Shah, S. Z. \& Iqbal, A., (2020). Impact of Foreign Remittances on Financial Development of Pakistan. Journal of Accounting and Finance in Emerging Economies, 6 (1), 331-342

DOI: $10.26710 /$ jafee.v6i1.1096 


\section{Introduction}

Flows of remittances are increasingly attracting attention into developing countries due to their growing capacity and their effect on recipient countries. Thus, researchers are on the opinion that remittances have the key role to play in the development of households, businesses and even for economic systems of developing countries. Remittances are overseas earnings, sent back from the host-country of employment to the country of origin (Kapur, 2003; Oke, 2011). As per International Organization for Migration (2006) remittances are the product of income earned connected with migration and defined as the cash transferred by immigrant or migrated worker in his country of origin to his relatives. Migrants send remittance to their family for routine (monthly) consumption purposes and to support them in their bad times.

Migrants' remittances have been growing extremely over the last twenty years. Since 2009, keeping the importance of remittances in consideration, the World Bank has acknowledged them in its measure of creditworthiness (Connor et al., 2013). Developing countries without having enough remittances level force to borrow otherwise from external sources like IMF (International Monetary Fund etc.) on restrict conditions. Workers' remittances, now a day, are the rudiments of emergent economies as these have proved to be more stable than other external inflows like foreign direct investment-FDI. Many researchers are on the opinion that for transitional countries most significant source of income is remittance, which comes after FDI (Ratha, 2005; Bettin and Zazzaro, 2011; Oke, 2011; Sirkeci, Cohen, \& Ratha, 2012). Consequently, these remittances can be used in numbers of way like poverty reductions, education, economic and financial development. Remittances also save the economies from different financial shocks and help in natural hazards. For instance, Pakistan received a lot of remittances during 2005 earth quick in Northern Pakistan and 2009 flood in Southern Punjab. However, this kind of increase in remittances depend on intentions and self-interest of remitters. Among others, financial development is most important one.

Among the top ten world countries receiving remittances Pakistan is one and in Asian countries it is on number fifth Asian ranking scale (Canuto \& Rafha, 2011, Mughal, 2013; Abbas et al., 2017). In 1982-83, the inflow was $\$ 2.88$ billion and in next five years it fluctuated (Abdel-Rahman, 2006). Again, it shoot up and inflows increased to $\$ 7$ billion in 2008 in Pakistan and accounted 4.2\% of total GDP (Kock \& Sun, 2011). In contrast with 2009-10 the quantity of remittances grew to 25.8\% in Pakistan in 2010-11 (SBP, 2011). In July to December 2012 the flows of remittances were $12 \%$ greater than previous year i.e. $\$ 7$ billion. Overseas Pakistanis sent remittances in 2012-13 to their residence were US\$13.2 billion (Sohaib, 2013). The workers' remittances have been made marvelous involvement in Pakistan to overall overseas' earnings of the nation (Mughal, 2013). The tremendous increase in flow of remittance to Pakistan consist of; raises number of immigrant, the increase of skilled-overseas to abroad that received high wages and incomes and shift of official channel (Arif \& Irfan, 2012).

Pakistan is facing upward trends in remittances from abroad (State Bank of Pakistan, 2015). In 2006 to 2007, Pakistan take delivery of $\$ 5.5$ billion overseas remittances. Pakistan got $\$ 6.4$ billion inflow of remittances in 2007-08 and $\$ 7.8$ billion in 2008-09. After that this trend increases remarkably with the passage of time as $\$ 8.9$ in $2009-10, \$ 11.2$ billion in $2010-11$, $\$ 13.2$ billion in $2011-12$, $\$ 13.9$ billion in 2012-13, $\$ 15.84$ billion in 2013-14 and in 2014-15 $\$ 18.45$ billion respectively (figure 1). 


\section{Figure 1: Overseas Remittances Trend in Pakistan}

\section{INTERNATIONAL REMITTANCES (US\$ BILLIONS)}

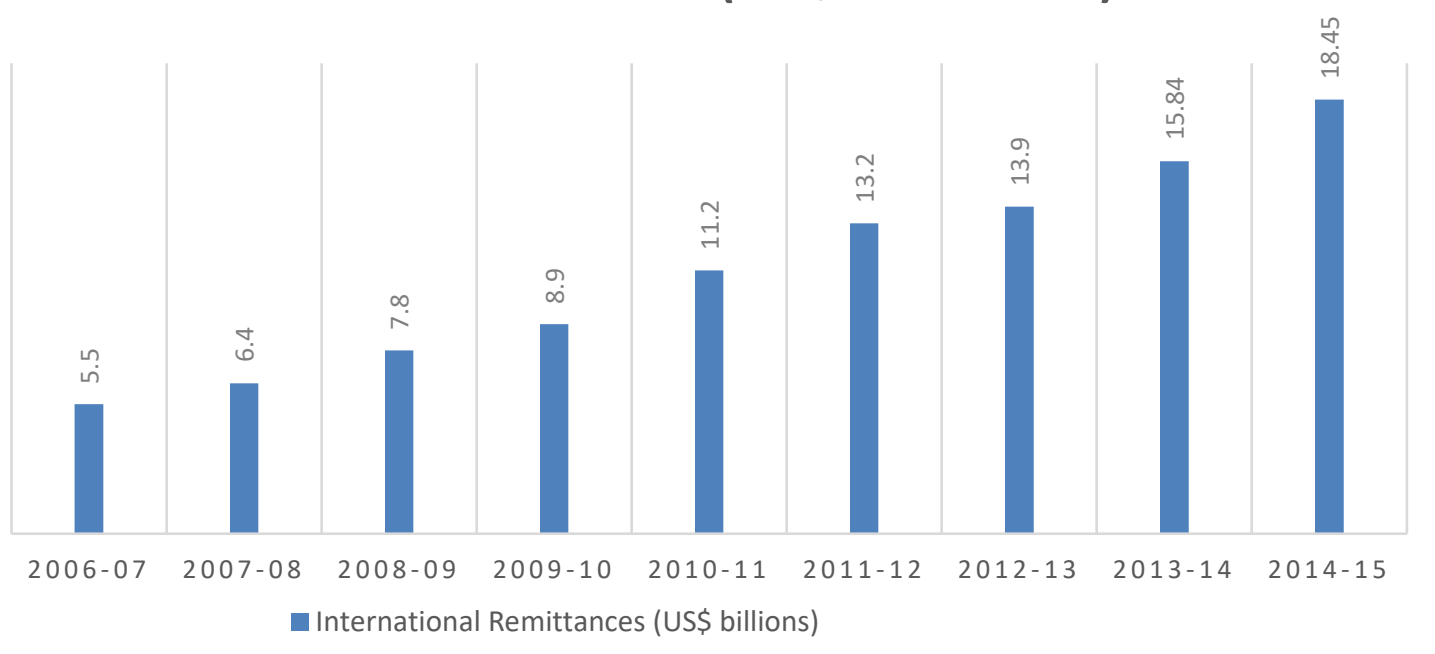

Source: State Bank of Pakistan (2015)

Studies have found that it is financial development-FD that decides to get advantage from remittances. Further these ensure adequate growth for any country particularly those countries who heavily rely on the inflows in the form of remittances. The development through remittance could be use in several ways. First, as is sound predictable, approach to credit is the main restraint for enterprising activities in transitional countries (Biggs and Shah, 2006; World Bank, 2009; Woodruff and Zenteno, 2007; Beck and Demirg uc,-Kunt, 2006; Bettin and Zazzaro, 2011). Second, remittances appear to additional FD in countries of origin play an important role in reducing inequality, poverty and promotion of economic growth (Demirg"uc,-Kunt et al., 2010; Gupta et al., 2009; Beck et al., 2007; Aggarwal et al., 2006 and Bettin and Zazzaro, 2011). Lastly, remittances should be used in a way that abolish liquidity constraints and promote access to credit for the remitters' families. Further these inflows should allow the funding for that businesses which boost growth by talented but financially poor individuals, if it would efficiently intermediated (Bettin and Zazzaro, 2011)

Although nexus between economic growth and remittance has been covered in literature but impact of remittances on FD is still theoretically unclear. The effort to inspire remittance receiver to lay remittances in the financial system by financial intermediaries showed the importance of inflows to the financial sector (Orozco and Fedewa, 2005). The fact is that while doing so, they covered the way for the consumers to approach to other financial services and products. So for as, remittances are considered to be stung up and established the banks, are able to give loans to the people and this will definitely put a strong and positive effect on the economy and development of the country. Furthermore, when the deposits of bank directly related to remittances flow will increase, then banks will be able to increase the loanable funds and this will positively soil the foundation in the growth of country's economy. In fact, in transitional economies remittances are helpful to reduce credit constraints (Woodruff and Zenteno, 2004 and Funkhouser, 1992). On the other hand, if recipient does not believe on financial institutions or consumed all remittance then the result would be contraction in bank deposits or loanable funds. Moreover, if bank favor to retain liquid assets relative to lending then remittances may not be helpful to increase private sector credit (Oke, Uadiale and Okpala 2011, Aggarwal, Demirguc-Kunt and Peria 2006, and Orozco and Fedewa, 2005).

After discussing remittances and FD in detail, it is derived that not only they boost economic growth but 
they also interrelated with each other. It is examined that commercial banks grow with increased remittances. A lot of financial services are acquired by the families of remitter as they invest their savings in new businesses and banks. In this way enormous profit earned by the families of remittance recipient country and as a result country's financial sector also developed. This is the reason behind that scholar and researcher examine the association between remittances of workers and FD in transitional countries. However, how to quantify accurately the FD of a country is still need to be covered. For instance, Aggarwal et al. (2011) and Oke et al. (2011) argued that FD is computed usually by investigating the level and size of financial intermediaries in a country while it can also be measured with the help of FD index. This part still need to be addressed particularly with regard to developing countries like Pakistan.

The previous literature on remittances have center of attention on their impacts on entrepreneurial activity, poverty and economic growth in Pakistan, whereas that on FD is scarce. So, this study discovers out this gap (to the best of researcher knowledge) and aims to investigate the impact of remittances on FD. Therefore, the study in hands is design to evaluate the nexus between remittances and FD and to found out whether remittances has any effect on the prevailing financial performance of Pakistan. Different from existing studies, we utilize more efficient measures for FD (e.g. measured by 1. domestic credit to private sector as percentage of GDP and 2. Money supply M2 as percentage of GDP in Pakistan). Moreover, while considering the recent financial situation of Pakistan l's economy, it is evident that the role of foreign financial inflow to domestic country has gained immense importance. The few developing countries including Pakistan whose important contributor in term of foreign exchange reserve is remittances, mostly rely on the inflow of their workers' remittances. Presently, as the country is facing chronic financial crises in terms of foreign exchange reserves, remittances are the only source to tackle the financial situation including terms of trade and overall balance of payment.

The remaining part of the paper is formed as follows. The second section is related to existing literature on nexus between remittances and various macroeconomics Third section presents a concise explanation of the data and methodology. Empirical results and investigation can be seen in the fourth section and the fifth section consists of conclusion and policy recommendation.

\section{2-Literature Review}

This section overviews literature review about the impact of remittances on FD, economic growth, terrorism and poverty reduction. Tahir (2008) analyzed, by taking time series data from 1973-2006, an investigation of the effectiveness of FD in Pakistan. To recognize the causality among economic and FD and the exogeneity of the variables in the model vector error-correction modeling is applied. It is concluded economic development is the basis of FD in the long-run. Another study checked the effect of workers' remittance on FD in Nigeria (Oke et al., 2011). The study used the time-series data from 19772009. The GMM (Generalized Method of Moments) and OLS (ordinary least square) techniques were applied to incorporate effect of explanatory variables on endogenous variable. It has been found that remittances impact significantly and directly on FD in Nigeria, apart from GMM in which worker remittances was insignificant. Aggarwal et al., (2011) explored the relationship between FD and remittance and aimed to find the role of remittances in FD in developing countries. In order to investigate this association fixed effects estimations and dynamic GMM system is employed on group panel of 109 developing countries from the period of 1975 to 2007. After controlling the reverse causality and measurement errors effects it is estimated that worker remittances and FD are directly and significantly associated with each other in the recipient developing countries.

Javid et al. (2012) shed light on the positive role of foreign remittances on uplifting Pakistan economy by eliminating poverty. By applying ARDL technique on the data of 1973-2010 shows that inflows through remittances have significantly positive effect on Pakistan's economic growth. The impact can be seen through regional economic growth of various districts of Baluchistan, Punjab and Sindh but the situation of Khyber Pakhtunkhwa (North-West-Frontier province-NWFP- at that time in 2010) is ambiguous. Pakistan can increase and utilize foreign remittances by formulating such policies that will enhance 
foreign remittance amount and motivate Pakistanis to transfer amount through proper channel by reducing transaction cost. Ahmad et. Al. (2013) figure out the foreign remittances on financial growth of Pakistan by adopting secondary time series data from 1978-2011. Utilizing the multiple regression analysis, the affiliation among the variables is depicted. Estimated results showed that foreign remittances and GDP of Pakistan have been positively correlated whereas negative association existed between inflation and exchange rate on economic growth. To improve investment and FD Pakistan needs stable and creative government to boost economic growth and foreign investment inflows.

Sharif et al. (2013) intended to study the effect of inflows on FD on Latin America and Caribbean region. They used panel data from 1991-2010 for 29 countries. Fixed and random effect panel regression methodology is used to check the bump of remittances. Empirical results indicated that FD positively and significantly affected by remittances. Valahzaghard \& Kashfi (2014) presented the picture of Iran during the period 2006-2011 aimed to check the impact of different variables including GDP, the rate of inflation, the depth of the financial market, the number of bank branches and interest charged by the banks on bank deposits. By employing regression analysis, it is indicated that there exist positive and significant correlation among GDP, rate of inflation, financial market depth and the number of bankbranches on bank deposits. Jawad \& Qayyum (2015) designed the collusion of policy environment and other macroeconomic determinants like GDP, interest rates, exchange rate and labor force participation rate on worker's remittances in Pakistan. The results revealed that there prevailed negative link in between growth of worker remittances and policy index and the GDP. At policy recommendation level, it has been recommended that there should be sound economic policies which attract flows of foreign remittances. Luqman \& Huq (2015) analyzed that whether remittances response to economic growth affected by a country's absorption capacity or not? To test that hypothesis ARDL Bound testing approach has been employed for the period of 1972-2011. Empirical results showed that economic growth has not significantly influenced by remittances attributed to local financial sector development. Mubeen et. al (2016) inspected the remittances impact on FD of Pakistan utilizing the data from 1980 to 2011. To express the relationship between variables multiple regression model has been adopted. The results revealed that workers' remittances, agriculture growth and FDI have positive impact on Pakistan's economic growth. It has been also suggested that for more development Pakistan should focus on large quantity of raw material and money goods trade. Abbas et al., (2017) studied the effect of macroeconomic (political and financial) factors on remittances for Pakistan by employing data from 1972 to 2012. The GMM methodology was applied to find out the impacts. Results indicated that due to unstable macroeconomic conditions remittances significantly and negatively affected by inflation and financial liberalization but positively affected by dummy variable of 2001 terrorist attacks. Qwader \& Alawneh (2017) in Jordan during the period of 2000-2015 measured the impact of earnings from remitters and economic stability on bank deposits. To check this bump multiple regression model has been used, which indicated that inflation rate and workers' remittances have been positively and significantly correlated with bank deposits, while rate of economic growth is negatively and significantly correlated with bank deposits. For policy recommendation, it is suggested that economic variables that sentiment the bank deposits in Jordan, should be given attention by the local bank administration. And also, local bank administration should provide honest and genuine programs that pull overseas workers' remittances and give both of them benefits alike.

After analyzing the above literature, it has been observed that most of the studies are related to the impact analysis of remittances with regard to economic growth and entrepreneurial activities (Hanson \& Woodruff, 2003; Adams \& Page, 2005; Yang, 2006; Barajas et al., 2009; Anyanwu \& Erhijakpor, 2010) whereas research on financial development is scarce. So, this study will try to fill this gap.

\section{Methodology}

The secondary data is taken from World Bank data and international monetary fund. For this purpose, the 
study utilizes the time series annual data for the period 1976-2015. To ascertain the desired linked among variables the model is follow:

$$
\mathrm{FD}=\emptyset_{0}+\beta_{1}(\mathrm{PREM})+\beta_{2}(\mathrm{GDP})+\beta_{3}(\mathrm{INF})+\beta_{4}(\mathrm{FDI})+\beta_{5}(\mathrm{TO})+\mu_{\mathrm{t}}
$$

Where;

FD is the financial depth (the ratio of money supply-M2- to GDP i.e. $\mathrm{M}_{2} / \mathrm{GDP}$ ) and measures the size of financial intermediaries as well as the level of financial intermediation. The second indicator of FD is the ratio of credit to private sector to GDP i.e. CPS/GDP. PREM is the current private transfers from migrant workers' resident in the host country to recipients in their home country for more than a year (Aggarwal, Oke, Uadiale and Okpala 2011; Sharif, Tufail and Amjad 2013). GDP is the growth variable which depicts the country size and measured by yearly GDP growth in terms of percentage (Aggarwal et al., 2011 and Fayissa and Nsiah, 2012). INF is inflation which quantifies by the annual customer prices in terms of percentage (Nyamongo, Misati, Kipyegon, \& Ndirangu, 2012; Giuliano \& Ruiz-Arranz, 2009). TO is the trade openness and will measure through ratio of imports and exports to GDP in terms of percentage. FDI is the foreign direct investment and it is the ratio of net inflows of foreign direct investment to GDP in terms of percentage. These are control variables and literature also showed the greater influence of these variables on FD. The aim, to include them is to explore the accurate impact of remittances on FD.

In this study ARDL model, presented by Pesaran et al. (2001), is applied because this estimation technique is suitable for small sample. Also, the unit root test of the study supports this technique. Through ARDL model long-run and short-run coefficients are computed simultaneously. The models are as:

$$
\begin{gathered}
\Delta X_{t}=\delta_{0 i}+\sum_{i=1}^{k} \alpha_{i} \Delta X_{t-i}+\sum_{i=1}^{k} \alpha_{2} \Delta Y_{t-i}+\delta X_{t-1}+\delta Y_{t-1}+v_{1 t} \ldots \ldots .2 . \\
\Delta Y_{t}=\delta_{0 i}+\sum_{i=1}^{k} \alpha_{i} \Delta Y_{t-i}+\sum_{i=1}^{k} \alpha_{2} \Delta X_{t-i}+\delta Y_{t-1}+\delta X_{t-1}+v_{1 t} \ldots \ldots . .3
\end{gathered}
$$

Where k shows the maximum lag order of ARDL model. F-statistic approved the joint null hypothesis that the coefficients of the lagged variables $\left(\delta 1 \mathrm{X}_{t-1} \delta 1 \mathrm{Y}_{t-1}\right.$ or $\left.\delta 1 \mathrm{Y}_{t-1} \delta 1 \mathrm{X}_{t-1}\right)$ are zero. $(\alpha 1-\alpha 2)$ represent the short-run dynamics while, $(\delta 1-\delta 2)$ correspond to the long-run relationship in the model. Thus, the hypothesis of the long-run relationship is formulated as given below:

Ho: $\delta 1=\delta 2=0$ (no long-run association)

$\mathrm{H} 1: \delta 1 \neq \delta 2 \neq 0$ (long-run association)

On the other hand, to check the short-run analysis vector error correction model was used which can be devised as follows;

$$
\Delta Y_{t}=-\emptyset E C_{t-1}+\sum_{i=1}^{k} \beta_{i 0} \Delta X_{i t}+\delta \Delta w_{t}-\sum_{j=1}^{p-1} \emptyset \Delta_{t-j}-\sum_{i=1}^{k} \sum_{j=1}^{q-1} \beta_{i j} \Delta x_{i, 1-j}+\mu_{t} \ldots \ldots 4
$$

ECt is the error correction term defined by;

$$
E C_{t}=\varepsilon_{t}=y_{t}-\sum_{i=1}^{k} \emptyset_{i} x_{i t}-\Psi \mathrm{w}_{\mathrm{t}} \ldots \ldots \ldots
$$


Where $\mathrm{EC}_{\mathrm{t}-1}$ represents the lag value of error correction drew from the long-run coefficients. The coefficient of error correction ' $\beta$ ' calculates the speeds of adjustment in which equilibrium is achieved.

\section{Empirical Results}

4.1 Unit Root Test

Augmented Dickey Fuller (ADF) and Phillips Perron (PP) unit root test are applied on the data to examine the stationarity and order of integration. Stationarity is important in the data, because, if trend exist spurious results created which are harmful. ADF and PP test involves fitting regression model:

$\Delta \mathrm{Y}_{\mathrm{t}}=\alpha_{0}+\delta \mathrm{Y}_{\mathrm{t}-1}+\alpha_{1} \mathrm{t}+\sum_{i=1}^{\mathrm{m}} \beta_{\mathrm{i}} \Delta \mathrm{Y}_{\mathrm{t}-\mathrm{I}}+\varepsilon_{\mathrm{t}} \ldots \ldots \ldots \ldots \ldots . . \ldots$

$\varepsilon_{\mathrm{t}}=$ white noise

$\alpha_{0}=$ intercept

$\delta, \alpha_{1}$ and $\beta_{i}=$ coefficients

Results of unit root test are presented in table 1. It shows that FD, PREM and FDI are stationary at first difference, i.e. I(1) while GDP, INF and TO are stationary at level, I(0). This established order of integration is benchmark to use the ARDL approach to find associations among macroeconomic variables through cointegration. Software Eviews 9 automatically select the optimal lag length for the variables through Akaike Information Criteria.

\section{Table 1: Unit Root Test}

\begin{tabular}{|l|l|l|l|c|}
\hline \multirow{2}{*}{ Variables } & \multicolumn{2}{|c|}{ ADF } & \multicolumn{2}{c|}{ PP } \\
\cline { 2 - 5 } & Levels & First difference & Levels & First difference \\
\hline$F D\left(M_{2} / G D P\right)$ & -1.615517 & -5.276116 & -1.633525 & $-6.687586^{*}$ \\
\hline$F D(C P S / G D P)$ & -1.505626 & -4.994417 & -1.387306 & $-4.994417^{*}$ \\
\hline$P R E M$ & -1.446256 & -5.879476 & -1.768467 & $-5.935833^{*}$ \\
\hline$G D P$ & $-4.010413^{*}$ & ---- & $-4.025204^{*}$ & ---- \\
\hline$F D I$ & -2.724214 & -4.092987 & -1.832116 & $-3.935959^{*}$ \\
\hline$I N F$ & $-5.723545^{*}$ & ---- & $-5.768580^{*}$ & ---- \\
\hline$T O$ & $-4.437799^{*}$ & ----- & $-4.514215^{*}$ & ---- \\
\hline
\end{tabular}

Note: *shows significance at 1\%. Null Hypothesis: There is unit root; Alternative Hypothesis: There is no unit root

\subsection{Cointegration Analysis}

Through Bound test analysis cointegration among variables is investigated. This is presented in table 2:

Table: 2 ARDL Bound Test

\begin{tabular}{|c|c|c|}
\hline \multirow{2}{*}{ F-statistic } & FD(cps/gdp) & FD(M2/gdp) \\
\cline { 2 - 3 } & 7.1947 & 5.3014 \\
\hline Significance & Critical Value Bounds \\
\hline $10 \%$ & I0 Bound & I1 Bound \\
\hline $5 \%$ & 2.26 & 3.35 \\
\hline $2.5 \%$ & 2.62 & 3.79 \\
\hline $1 \%$ & 2.96 & 4.18 \\
\hline
\end{tabular}


The results depict that F-statistics are 7.1947 and 5.3014 respectively which are greater than upper bound critical value at $10 \%, 5 \%, 2.5 \%$ and $1 \%$ level of significance. This means that alternative hypothesis of cointegration is accepted and it is concluded that there is cointegration among macroeconomic variables. So ARDL technique can be employed to estimate the long-run associations.

\subsection{Long-run Estimated Results}

After estimating the cointegration among coefficients long-run relationship is computed through ARDL technique. Table 3 portray the relationship.

Table: 3 ARDL: Long Run estimated results

\begin{tabular}{|c|c|c|}
\hline Dependent Variable: FD & FD $(\mathbf{c p s} / \mathbf{g d p})$ & $\mathbf{F D}_{\mathbf{2}}$ (M/gdp) \\
\hline Variables & 1.482360 & $1.366038^{* *}$ \\
\hline $\boldsymbol{P R E M}$ & $(1.019167)$ & $(0.569832)$ \\
\hline $\boldsymbol{G D P}$ & $7.283390^{* *}$ & $-2.124570^{* *}$ \\
& $(1.534895)$ & $(0.882644)$ \\
\hline $\boldsymbol{F D I}$ & 1.972564 & $7.563867 *$ \\
& $(0.951290)$ & $(1.558973)$ \\
\hline $\boldsymbol{I N F}$ & $-2.689720^{*}$ & -0.529306 \\
& $(0.256718)$ & $(0.362257)$ \\
\hline $\boldsymbol{T O}$ & $\{0.0019\}$ & 0.046776 \\
& $1.768809^{* * *}$ & $(0.684972)$ \\
\hline $\boldsymbol{C}$ & $(0.741235)$ & $47.848197 *$ \\
& $27.567503^{* *}$ & $(5.294091)$ \\
\hline Observations & $(6.508267)$ & 40 \\
\hline
\end{tabular}

*shows variables are significant at 1\%, ** shows variables are significant at 5\%, *** shows variables are significant at $10 \%$

The results delineate that in the long-run FD is significantly affected by workers' personal remittances when computed by the ratio of money supply to GDP. But when FD is computed as the ratio of credits to private sector, financial development is not significantly but positively influenced by remittances in Pakistan. This might be due to the reason that most of Pakistanis living abroad send remittance through informal sources (Hundi and friends). If they send through banking sectors, then remittances can be used for development of the country. Therefore, study recommends that government of Pakistan should encourage Pakistani expatriates to send the remittances through formal sources (e.g. banks). It is concluded that a $1 \%$ increase in remittances would enhance financial development by $1.4823 \%$ and $1.3660 \%$, respectively as indicated by the results in Table 3. The results are in agreement with previous literature (Chowdhury, 2011; Esteves and Khoudour-Castéras, 2011; Fayissa and Nsiah, 2012).

Theoretically, higher amount of remittances increases the consumption level of the recipient country that results in higher economic growth by inducing more investment. It is evident from our results (Table 3; Model 1) that FD positively affected by economic growth of the country in column 2 but negatively influenced by growth in column 3 (Model 2). The results are supported by previous study for first model (Ubreen and Nawaz, 2014).

As expected, inflation has negative impact on financial development in both models and with both financial development indicators. However, in first model it has significant impact while in second model it opposite case is true. Generally, as noted by (Rashid and Husain, 2013), more capital inflows (in form of remittances) to the domestic country generates inflation. In this case our results are contradicts. This 
might be due the reason that outflows (through money laundering) from the country is very higher and remittance has insignificant impact on financial development (model 1). It means that financial development of the country is more determined by other macroeconomics factors such as inflation, FDI and trade openness as compared to remittance. Policy here, again, to channelize the remittances through formal sectors. This is evident from our results (Table 3) that foreign direct investment and trade openness have positive but inflation has negative impact on financial development.

\subsection{Short-run Estimated Results}

While considering the short run estimated results, we get some important conclusions. The estimated results of table 4 are derived through running our ARDL model through econometric software eviews. In short period of time, remittances have positive impact on FD whether it is measured by broad money or credit to private sector. $\mathrm{M}_{2}$ to GDP and credit to private sector have significant positive effect on FD. As workers' remittances boost one percent financial development also boost by 0.5154 and 0.5558 percent, respectively. Same as in the long run, also, in the short-run financial development positively affected by foreign direct investment and trade openness while inversely influenced by inflation and country size. Country size has opposite sign according to the expectation but supported by the literature (Oke et al., 2011; Sharif et al., 2013).

The coefficient of ECM $\mathrm{E}_{\mathrm{t}-1}$ implies that how quickly or slowly variables return to equilibrium and it should be highly significant with negative sign. The model fulfils this property of error correction term. Error correction term indicates modification speed which is required to re-established equilibrium in short-run model. The coefficient of $\mathrm{ecm}_{\mathrm{t}-1}$ is -0.2594 for short-run model. It narrates that deviation from the long run financial development is corrected by $25.94 \%$ over each year. The value of coefficient $\left(\mathrm{R}^{2}\right)$ is .9197 which depict that 91 percent deviation in dependent variable is because of independent variable and the rest is because of error term. F-Statistics tell the significance of whole model. This model is significant at $5 \%$ level of significance with value 432.59 .

\section{Table: 4. Short-run Dynamics based on ARDL}

\begin{tabular}{|c|c|c|}
\hline \multicolumn{3}{|c|}{ Dependent Variable: FD } \\
\hline Variables & FD $1($ cps/gdp) & $\mathrm{FD}_{2}\left(\mathrm{M}_{2} / \mathrm{gdp}\right)$ \\
\hline D $($ PREM $)$ & $\begin{array}{c}0.515404^{* *} \\
(0.138830) \\
\end{array}$ & $\begin{array}{c}0.555839 * * \\
(0.285072) \\
\end{array}$ \\
\hline$D(G D P)$ & $\begin{array}{l}-0.015639 \\
(0.086371) \\
\end{array}$ & $\begin{array}{c}-0.239091 \\
(0.314561) \\
\end{array}$ \\
\hline$D(G D P(-1))$ & $\begin{array}{c}-0.070478 \\
(0.085956)\end{array}$ & $\begin{array}{c}0.090820 \\
(0.237057)\end{array}$ \\
\hline$D(G D P(-2))$ & $\begin{array}{c}-0.924714 * \\
(0.132866)\end{array}$ & $\begin{array}{c}0.477679 * * \\
(0.204192)\end{array}$ \\
\hline$D(F D I)$ & $\begin{array}{l}2.290517 * \\
(0.265532) \\
\end{array}$ & $\begin{array}{l}3.077727 * \\
(0.858864) \\
\end{array}$ \\
\hline$D(I N F)$ & $\begin{array}{c}-0.478212 * \\
(0.035393) \\
\end{array}$ & $\begin{array}{c}-0.215374 * * * \\
(0.118048) \\
\end{array}$ \\
\hline$D(T O)$ & $\begin{array}{c}0.164491 * * * \\
(0.057110)\end{array}$ & $\begin{array}{c}0.019033 \\
(0.279198)\end{array}$ \\
\hline $\operatorname{CointEq}(-1)$ & $\begin{array}{c}-0.259472 * \\
(0.032383)\end{array}$ & $\begin{array}{c}-0.406899 * \\
(0.130564)\end{array}$ \\
\hline
\end{tabular}




\begin{tabular}{|c|c|c|c|}
\hline \multicolumn{2}{|c|}{$\begin{array}{c}\text { Cointeq }=\text { DCPS }-(-4.4824 * \text { PREM }+ \\
7.2834 * \text { GDP }+1.9726 * \text { FDI }-2.6897 * \text { INF + } \\
1.7688 * \mathrm{TO}+27.5675)\end{array}$} & \multicolumn{2}{|c|}{$\begin{array}{c}\text { Cointeq }=\text { BRMO }-(1.3660 * \mathrm{PREM}- \\
2.1246 * \mathrm{GDP}+7.5639 * \mathrm{FDI}-0.5293 * \mathrm{INF}+ \\
0.0468 * \mathrm{TO}+47.8482)\end{array}$} \\
\hline R-Squared & \multicolumn{2}{|c|}{0.919756} & 0.862315 \\
\hline Adjusted R-Squared & \multicolumn{2}{|c|}{0.905265} & 0.816420 \\
\hline Akaike Inf Criterian & \multicolumn{2}{|c|}{-1.108258} & 4.759957 \\
\hline Schwarz Criterian & \multicolumn{2}{|c|}{0.313775} & 5.195340 \\
\hline Durbin-Watson Stat & \multicolumn{2}{|c|}{2.257380} & 1.974015 \\
\hline F-statistic & \multicolumn{2}{|c|}{432.5988} & 18.78890 \\
\hline $\operatorname{Prob}(F$-statistic $)$ & \multicolumn{2}{|c|}{0.000157} & 0.000000 \\
\hline
\end{tabular}

The overall results depict that financial development positively and significantly affected by workers' remittances. Literature support these findings as positive relation among financial development and remittances has been proved by many studies (Gupta et al., 2009; Esteves \& Khoudour-Castéras, 2011; Oke et al., 2011; Aggarwal et al., 2011; Fayissa \& Nsiah, 2012).

\subsection{Diagnostic tests}

Various diagnostic tests are applied to check serial correlation, conditional hetroscedasticity and normality for the model as can be seen in Table 5 which is derived by performing the post-estimations diagnostics checks in eviews software.

\section{Table: 5 Diagnostic Tests}

\begin{tabular}{|l|c|c|}
\hline Diagnostics & FD(cps/gdp) & FD(M/gdp) \\
\hline Breusch-Godfrey Serial & $(0.347883)$ & $(1.384075)$ \\
Correlation LM Test & $\{0.0549\}$ & $\{0.1581\}$ \\
\hline Heteroskedasticity Test: & $(0.345852)$ & $(1.559495)$ \\
Breusch-Pagan-Godfrey & $\{0.6546\}$ & $\{0.1788\}$ \\
\hline Normality Test: & $(0.742659)$ & $(0.307982)$ \\
Jarque-Bera Test & $\{0.6898\}$ & $\{0.8572\}$ \\
\hline
\end{tabular}

For auto-correlation Bruesh-Godfrey LM test is applied and the test confirm the absence of autocorrelation. Bruesch-Pagan-Godfrey test is applied for testing hetro-scedasticity in which null hypothesis of homoscedasticity is acceptd against the alternative hypothesis in both models. To test the normality of both models Jarque-Bera Test is estimated and it also ensures that the residuals are normally distributed. So the empirical results demonstrate that short-run models surpass all the diagnostic tests.

\section{Conclusion \& Policy Recommendations}

The nexus among financial development-FD and workers remittances have been investigated in the present study. ARDL bound testing approach to co-integration is employed to check the nature and magnitude of correlation between running macro-economic variables. Annual time series data is utilized over the period of 1976 to 2015. Furthermore, to discover adequacy of the model various diagnostic techniques are operated. Empirical results of the study reveal that worker's remittances have significant positive influences on FD when measured by the ratio of money supply to GDP. But the remittances have insignificant impact on credit to private sector in terms of GDP. The fact behind this result is that in Pakistan liquid liabilities are more enhanced by remittances than loanable funds. What it means that in Pakistan remittances are more likely to exploit for consumption intention than for productive endeavors. Moreover, our study recommend is that the concerned institutions should expedite the channels of incurring remittances to the country. In this regard, the government should re-structure the transmission channels of foreign remittances in order to avoid the loss of financial revenue 
It is obvious, after analyzing the finding, that if Pakistan channelizes his inflow of remittances then financial segment of the country will improve. Financial institutions and intermediaries working in Pakistan should also exaggerate the recruitment of remittances with the purpose to make them significant source for loanable funds. Now the big challenge faced by Central Bank of Pakistan is to efficiently use these augmented inflows that significantly effect financial development.

\section{References}

Abbas, F., Masood, A., \& Sakhawat, A., (2017). What determine remittances to Pakistan? The role of macroeconomic, political and financial factors, Journal of Policy Modeling, 39(3), 519-531. DOI: https://doi.org/10.1016/j.jpolmod.2017.03.006

Abdel-Rahman, A. M. M., (2006). The determinants of foreign worker remittances in the Kingdom of Saudi Arabia. Journal of King Saud University, 18(2), 93-121.

Aggarwal, R., \& Peria, M. S. M., (2006). Do workers' remittances promote financial development? (Vol. 3957). World Bank Publications.

Amjad R., Irfan M., \& Arif G., (2013). How to increase formal inflows of remittances: An analysis of the remittance market in Pakistan. Working Paper, A joint publication of Lahore School of Economics (LSE), International Growth Center (IGC) and the Pakistan Institute of Development Economics (PIDE).

Beck,T., Demirg“uc-Kunt, A. \& Levine,R., (2007). Finance,inequalityandthepoor, Journal of Economic Growth, 12, pp. 27-49.

Beck,T. \& Demirg"uc,-Kunt, A., (2006). Smallandmedium-sizeenterprises:accesstofinance as a growth constraint, Journal of Banking and Finance, 30(11), 2931-43.

Bettin, G., \& Zazzaro, A., (2012). Remittances and financial development: substitutes or complements in economic growth?, Bulletin of Economic Research, 64(4), 509-536. DOI: https://doi.org/10.1111/j.14678586.2011.00398.x

Biggs, T. \& Shah, M. K., (2006). African SMES, networks, and manufacturing performance, Journal of Banking and Finance, 30(11), 3043-66.

Brown, R. P. C., Carmignani, F., \& Fayad, G., (2011). Migrants' Remittances and financial Development: Macroand Micro-level Evidence of a Perverse Relationship. OxCarre Working Papers.

Canuto, O., \& Rafha, D., (2011) Migration and Remittances. Factbook 2011.

Connor, P., Cohn, D., \& Gonzalez-Barrera, A. (2013). Changing patterns of global migration and remittances: More migrants in US and other wealthy countries; more money to middle-income countries. Retrieved from https://blog.riamoneytransfer.com/role-of-remittances-in-shaping-the-economy/\#_ftnref1.

Demirgüç-Kunt, A., Córdova, E. L., Pería, M. S. M., \& Woodruff, C. (2011). Remittances and banking sector breadth and depth: Evidence from Mexico. Journal of Development Economics, 95(2), 229-241. DOI: https://doi.org/10.1016/j.jdeveco.2010.04.002

Funkhouser, E., (1992). Migration from Nicaragua: Some Recent Evidence, World- Development, 20(8) 12091218, http://dx.doi.org/10.1016/0305-750X(92)90011-J

Sun, M. Y., \& Kock, U. (2011). Remittances in Pakistan: Why have they gone up, and why Aren't they coming down? (No. 11-200). International Monetary Fund.

Mughal, M. Y., (2013). Remittances as development strategy: Stepping stones or slippery slope?, Journal of International Development, 25(4), 583-595. DOI: https://doi.org/10.1002/jid.2891

Oke, B. O., Uadiale, O. M., \& Okpala, O. P., (2011). Impact of Workers' Remittances on Financial Development in Nigeria, International Business Research, 4(4), 218-225.

Ratha, D. (2005). Workers' remittances: an important and stable source of external development finance. Remittances: development impact and future prospects, 19-51.

Sirkeci, I., Cohen, J. H., \& Ratha, D., (2012). Migration and Remittances during the Global Financial Crisis and Beyond: World Bank Publications.

Sohaib, M. (2013). New Saudi labour laws may restrict remittances to Pakistan [Online]. The Express Tribune. 
Available: $\quad$ http://tribune.com.pk/story/570487/new-saudi-labour-laws-may-restrict-remittances-topakistan/. (Accessed 2 February 2015)

Woodruff, C., \& Zenteno, R. (2004). Remittances and Micro enterprises in Mexico, IR/PS Working Paper, http://dornsife.usc.edu/IEPR/Events/Papers/Christopher_Woodruff.pdf

Woodruff, C., \& Zenteno, R. (2007). Migration networks and microenterprises in Mexico. Journal of development economics, 82(2), 509-528..

World Bank, (2009). Banking the Poor: Measuring Banking Access in 54 Economies, Washington, DC: World Bank. 